\title{
Konseling Islam: Studi terhadap Posisi dan Peta Keilmuan
}

\author{
Hajir Tajiri \\ UIN Sunan Gunung Djati Bandung \\ E-mail: hajir_tajiri@yahoo.co.id
}

\begin{abstract}
Islamic counseling positions are in the debate between education, psychology and dakwah. All of them have a chance to develop Islamic counseling further. Educational counseling regards as one of the approaches in education and has had a very long history. Meanwhile counseling psychology claims as part of the work is the application of psychology and psychologists called counseling psychologists. In the middle of the debate, in Islamic science, it is dakwah science has been developed what is called irsyad and formula is not much different from counseling, just because it is in dakwah domain, it is shades of religious activity. Dakwah looked more entitled to counseling skills, because in dakwah, counseling activities that have been carried out by Muslims and fused with the dakwah activities.
\end{abstract}

\section{Kata Kunci:}

Konseling Islam, Posisi Keilmuan dan Peta Keilmuan

\section{A. Pendahuluan}

Salah satu fenomena menarik dalam diskursus keilmuan saat ini adalah berkait dengan posisi dan peta keilmuan konseling Islam. Konseling Islam secara tarik-menarik diklaim oleh sekurang-kurangnya tiga bangunan ilmu: psikologi, pendidikan dan dakwah. Tarik menarik ini sangat boleh jadi karena layanan bantuan yang bernuansa psikologis, serta tujuan yang akan dicapai oleh ketiga ilmu itu dalam bentuk layanan kepada orang yang membutuhkan. Fenomena tarik-menarik bukan hanya terjadi pada lingkup akademik, akan tetapi juga pada 
lingkup pengembangan profesi. Kalangan psikolog seringkali mengklaim konseling merupakan bentuk kerja atau aplikasi psikologi atau disebut psikologi konseling, beberapa instrumen yang telah berhasil diciptakan sangat berguna dalam rangka assesment masalah perilaku, dan data hasil olahannya sangat berguna bagi langkah konseling. Psikolog memproteksi hasil temuannya dengan melarang keras setiap upaya pihak lain yang ingin menggunakan instrumen ciptaannya kecuali mereka meminta izin sebelumnya, itupun harus melalui proses yang panjang.

Sementara itu dunia pendidikan juga mengklaim sebagai pihak yang paling berhak menggunakan jasa pelayanan konseling, sebab jika menilik kepada sejarahnya dan secara empirik konseling telah berkembang pesat pada dunia pendidikan, di Barat sejak awal abad 20an dan di Indonesia sekitar tahun 1975. Mulai tahun 1970-80 Bimbingan dan Konseling masuk ke dalam kurikulum Sekolah Menengah di negeri-negeri yang mengambil sistem pendidikan Barat (Mubarok, 2000:70).

Selain pendidikan dan psikologi, Ilmu dakwah dalam pengembangannya telah melahirkan sejumlah bentuk kegiatan dakwah, salah satunya irsyadul Islam. Bentuk kegiatan ini menyerupai konseling, dan secara meyakinkan menyebut dirinya konseling Islam. Seperti halnya pendidikan yang mengklaim bagian darinya karena sejarah perkembangan yang berada di dunia pendidikan, Ilmu dakwah melihat konseling Islam sebagai kegiatan yang sudah sangat tua, bersamaan dengan diutusnya para Rasul ke dunia dan mengajak umat manusia kepada cara hidup Islam. Apakah ketiga ilmu ini tidak bisa dipertemukan? Apakah alasan yang sebaiknya dikemukakan seandainya sebuah fakultas ingin membuka program studi Konseling Islam?

Khususnya konseling sebagai salah satu bentuk dakwah, menarik diungkap sejak kapan praktek konseling mulai dikenal dalam Islam, dan kapan fenomena konseling ini mulai ramai dibicarakan di kalangan ilmuwan muslim? Seperti apakah konsep konseling Islami ini berkembang di dunia Islam? Apakah konseling Islam memiliki hubungan dengan konseling yang berkembang pada ilmu pendidikan, psikologi dan ilmu dakwah? Dimana letak konseling Islam pada ketiga ilmu itu, apakah melekat pada masing-masing ketiganya atau berdiri 
sendiri? Apa hubungannya dengan konsep konseling bernuansa agama yang berkembang di Barat? Apakah konseling yang berkembang di Barat dalam beberapa hal juga masih relevan dan dapat diterima sebagai bagian dari proses berkembangnya konseling Islam?

\section{B. Akar Pertumbuhan Konseling Islam}

Praktik konseling dalam Islam bukanlah hal baru, ia telah ada bersamaan dengan diturunkannya ajaran Islam kepada Rasulullah SAW. Ketika itu konseling merupakan bentuk cara dakwah yang dilakukan oleh Rasulullah. Praktik-praktik Nabi dalam menyelesaikan problemproblem yang dihadapi oleh para sahabat ketika itu, dapat dicatat sebagai suatu interaksi yang berlangsung antara konselor dengan konseli, baik secara kelompok (misalnya pada model halaqah ad-dars) maupun secara individual (Lubis, 2007: 80).

Layanan konseling pada masa Nabi didorong oleh kondisi masyarakat problematik dan kondisi budaya jahiliyah masa itu. Jadi faktor yang memfasilitasi dilangsungkannya layanan konseling bagi masyarakat Arab pada waktu itu adalah situasi jahiliyah di satu sisi dan sifat atau watak ajaran Islam pada sisi yang lain. Islam adalah agama ilmu, dalam arti sebagai agama yang menjunjung tinggi nilai ilmu pengetahuan, mengajarkan prinsip-prinsip ilmu pengetahuan untuk menghantarkan manusia ke tingkat kecerdasan. Islam juga merupakan agama cahaya, dalam arti dengan petunjuk-petunjuk dan isyarat-isyarat ilmiah yang diajarkan, ia akan menjadi pedoman bagi manusia untuk merambah jalan kehidupannya menuju tujuan akhir kehidupan sesuai kehendak Allah.

Sebagai seorang konselor, Nabi mempergunakan seluruh waktunya untuk menyebarluaskan ajaran Islam melalui perkataan dan perbuatan. Nabi mendatangi para sahabat atau sahabat datang kepada Nabi untuk bertemu muka atau mengadakan kontak pribadi, baik secara kelompok maupun secara individual. Pada periode Mekah Nabi telah menentukan suatu tempat yang dinamakan Darul Arqam, untuk berkumpul, bertemu dan melakukan sosialisasi ajaran Islam kepada para sahabat. Sebelumnya Nabi juga secara proaktif menemui orang yang dianggapnya dapat dipercaya untuk memperkenalkan kepada mereka secara face to face dan secara sembunyi-sembunyi atau rahasia 
(sirr). Dengan kualitas personal yang dimilikinya serta pendekatan kognitif yang dipergunakannya, besar pengaruhnya terhadap sikap penerimaan para sahabat terhadap seruan atau ajakan Nabi. Pada periode ini jika ditilik dengan pendekatan konseling kontemporer barangkali memunculkan pertanyaan, apakah benar Nabi sudah melakukan konseling? Apakah upaya yang telah dilakukan Nabi itu konseling atau dakwah saja, bukan irsyad atau taujih. Segi perbedaan dakwah yang dilakukan pada periode ini dengan konseling yang berkembang di era kontemporer, bahwa individu/konseli menyadari kesulitan hidup yang dialami, sementara pada zaman Nabi yang dikenal dengan masa jahiliyyah itu seperti belum banyak yang menyadari terhadap kekeliruan yang dialaminya. Ahmad (1996) menyebutkan bahwa para pembesar dan penguasa masa bodoh dengan ketidaksadaran masyarakat dan betah dengan kedhaliman yang dimilikinya karena dengan itu mereka mampu meraup kesejahteraan dan sebaliknya jika rakyat kebanyakan sadar dengan kelemahan akan dianggap sebagai ancaman atas jaminan hidupnya.

Namun demikian, apakah terhadap kondisi individu-individu yang tidak sadar itu, tertutup peluang dilakukannya konseling? Ketika masyarakat Arab Jahiliyyah menyembah kepada berhala sebagai tuhannya, ketika tradisi masyarakat Arab harus membunuh setiap bayi perempuan yang lahir sebagai manifestasi kepatuhannya, ketika seorang ibu yang suaminya meninggal harus rela menyerahkan dirinya sebagai barang waris bagi anak laki-lakinya. Fakta perilaku yang tidak manusiawi itu, tidak sulit untuk mengatakan bahwa itu semua merupakan kumpulan masalah. Boleh jadi dalam aktivitas dakwah yang dilakukan Nabi, di dalamnya terkandung dua wilayah penamaan dakwah yaitu tabligh dan irsyad. Kegiatan sosialisasi dan seruan merupakan tugas tabligh sedangkan tindak lanjut seruan berupa pengembangan potensi kesadaran, memperkuat kesadaran, merupakan wilayah garapan mursyid. Mubaligh merupakan pekerja sales sedangkan mursyid pekerja jasa perbantuan.

Hayatuhu kulluhu da'wah, demikian julukan yang tepat bagi Rasul, dan diantara bentuk dakwah itu dilakukan dalam bentuk bimbingan dan konseling. Menurut Lubis (2007: 82), bimbingan yang dilakukan oleh Nabi mulai dari bimbingan yang bersifat spiritual hingga meluas ke bimbingan mencakup kehidupan material. Selain itu, bimbingan yang 
bersifat spiritual-kognitif banyak dilakukan oleh Nabi pada kurun Mekah, masyarakat Mekah diseru untuk menerima keyakinan Islam yaitu melalui kegiatan pengenalan keyakinan baru yang lebih rasional, lebih bersih, dan lebih sesuai dengan fitrah kemanusiaan. Upaya konseling Nabi dengan memperbaiki keyakinan, mengubah mindset tentang ketuhanan, seraya mengangkat model contoh perjuangan nabinabi terdahulu seperti Nabi Ibrahim AS, Nabi Musa AS, dan lain-lain. Hasilnya adalah kualitas muslim pada pengikut pertama yang dikenal assâbiqûn al awwalûn seperti Abu Bakar, Khadijah, Bilal bin Rabah, Ali bin Abi Thalib.

Sedangkan bimbingan dengan ranah permasalahan yang lebih luas banyak berlangsung di Madinah. Pada masa ini bimbingan tidak hanya bersifat spiritual-kognitif, tetapi juga meluas menyangkut kehidupan material. Bahkan bukan hanya melayani kaum muslimin melainkan juga melayani non-muslim dengan penuh toleransi dan dengan memperlihatkan sikap simpatik.

Konseling ala Rasulullah merupakan model utama rujukan para konselor muslim. Perjalanan konseling ala Rasulullah telah terbukti sukses dalam menghantarkan manusia kepada kehidupan yang baik. Betapa banyak contoh peristiwa dakwah yang dilakukan Rasul mengambil bentuk pelaksanaan bimbingan dan konseling. Dikemukakan Mubarok (2000: 81-82), dalam hadis yang diriwayatkan oleh Ahmad dari Abu Umamah, diilustrasikan,

...seorang pemuda mendatangi Rasul dan bertanya secara lantang di hadapan orang banyak; Wahai Nabi Allah, apakah engkau dapat mengizinkan aku untuk berzina? Mendengar pertanyaan yang tidak sopan itu orang-orang ribut mau memukulinya, tetapi Nabi segera melarang dan memanggil, bawalah pemuda itu dekat-dekat padaku. Setelah pemuda itu duduk di dekat Nabi, maka Nabi dengan santun bertanya kepada pemuda itu: Bagaimana jika ada orang yang akan menzinahi ibumu? Demi Allah aku tidak akan membiarkannya, kata pemuda itu. Nabi pun meneruskan, nah begitu pula orang tidak akan membiarkan hal itu terjadi pada ibu mereka. Bagaimana jika terhadap anak perempuanmu? Tidak, demi Allah, aku tidak akan membiarkannya, kata pemuda itu. Nabi melanjutkan, bagaimana jika terhadap saudara perempuanmu? 
Tidak juga, ya Rasul demi Allah aku tidak akan membiarkannya, kata pemuda itu. Nabi meneruskan, Nah begitu juga orang tidak akan membiarkan puterinya atau saudara perempuannya atau bibinya dizinahi. Nabi kemudian meletakkan tangannya ke dada pemuda itu sambil berdo'a; Ya Allah bersihkanlah hati pemuda ini, ampunilah dosanya dan jagalah kemaluannya.

Contoh lainnya, dapat dilihat dalam kitab Syarah al-Kirmani Juz 18 halaman 195, yang secara garis besar menggambarkan peristiwa berikut:

Dalam suatu penyelenggaraan jenazah Nabi bersabda, 'setiap kamu telah ditentukan nasibnya di surga atau di neraka'. Para sahabat bertanya: "Jika demikian, apakah tidak lebih baik kita berserah pada nasib yang sudah ada itu dan kita tidak perlu lagi beramal?". Nabi menjawab: "Beramallah kamu, karena setiap orang akan dipermudah ke arah nasib itu. Bagi orang berbahagia akan dipermudah ke arah pencapaian kebahagiaan itu, demikian pula bagi orang sengsara akan dipermudah ke arah kesengsaraan itu". Kemudian Nabi membacakan ayat Qur'an surat al-Lail ayat 5 sampai 10, yang menjelaskan bahwa Allah akan memberikan jalan kemudahan menuju surga kepada hamba-Nya yang berinfak dengan dasar takwa dan yakin akan balasan Allah, tetapi akan mempersulit bagi hambaNya yang bakhil dan merasa dirinya super serta tidak yakin akan balasan pahala dari Allah (Lubis, 2007:90).

Dalam sejumlah al-hadits lainnya sebagaimana dihimpun Suparta dkk. (2006: 251-252), juga dapat ditemukan sejumlah praktek dakwah Nabi dalam bentuk konseling, pendekatan konseling Nabi memiliki cirri memperbaiki perilaku, menunjukkan kepada praktek hidup yang benar, antara lain dapat disebutkan:

1. Dari Abu Hurairah ra:: Bahwa seorang laki-laki telah berkata kepada Nabi saw.: "Berilah aku nasihat". Nabi menjawab: "Janganlah engkau jadi pemarah." Laki-laki itu kembali beberapa kali dan Nabi saw. Bersabda; "Janganlah kamu jadi pemarah." (HR. Bukhari).

2. Rasulullah saw bersabda: "Hendaklah kalian berlaku lemah lembut, karena kelembutan itu adalah baik keseluruhannya. Tiada kelembutan itu berada dalam sesuatu, kecuali menambah 
keelokan dan keindahan padanya, dan tiada dicabut kelembutan itu kecuali menjadikan sesuatu itu lebih jelek dan semakin buruk."

3. Rasulullah saw bersabda: "Barangsiapa yang tiba waktu ajalnya, sedang ia dalam suasana menuntut ilmu, maka ia akan menjumpai robbnya dimana tiada perantara baginya dengan para nabi atau derajat kenabian. Apabila maut datang kepada seorang yang menuntut ilmu dan dikala itu ia meninggal, maka dia tergolong kepada orang yang mati syahid di jalan Allah".

4. Nasihat Nabi tentang harta, "Sesungguhnya harta itu menyilaukan dan menyenangkan, barangsiapa memperolehnya dengan kelapangan hati maka harta itu akan membawa berkah baginya. Dan barangsiapa yang memperolehnya dengan hati yang rakus maka harta itu tidak akan membawa berkah, dan ia laksana orang yang banyak makannya akan tetapi tidak mengenyangkan".

5. Nasihat Nabi tentang etika berbusana. Diriwayatkan dari Jabir bin Abdullah r.a dia berkata, Rasulullah datang mengunjungi rumah kami lantas beliau menyaksikan ada seorang laki-laki yang rambutnya acak-acakan, maka beliau bersabda, "Apa anda tidak mempunyai sesuatu yang bias digunakan untuk merapihkan rambut?"

6. Nasihat Nabi kepada Muadz bin Jabal karena saat menjadi iman ia membaca surat yang panjang-panjang sehingga menimbulkan keresahan pada jama'ahnya. Kata Rasul, “Hai Muadz apakah kamu ingin menjadi tukang fitnah, engkau memanjangkan bacaan surat dalam shalat padahal di belakangmu itu ada orang yang lanjut usia, anak-anak kecil dan orang sakit."

7. Nasihat Nabi tentang perilaku laki-laki yang menyerupai wanita. Diriwayatkan oleh Ibn Abbas r.a., Rasulullah telah melaknat kaum pria yang berperilaku seperti wanita atau sebaliknya. Bahkan beliau bersabda, keluarkan dia dari rumahmu!

Contoh-contoh ini hanya sekelumit saja dari sekian banyak praktek konseling Nabi, Al-Qur'an yang intinya sebagai petunjuk, 
penjelasan terhadap beberapa petunjuk, pedoman perilaku, obat penawar, pembeda hak dan bathil, menjadi bukti betapa jelasnya paradigm atau ciri konseling yang dipraktekkan Nabi, suatu pendekatan ilahiyah, suatu pendekatan yang berorientasi pada pencapaian kebahagiaan dan keselamatan dunia dan akhirat, suatu pendekatan yang bertumpu pada akar masalah kehidupan manusia.

\section{Hisbah: Model Konseling Islam Klasik}

Menurut Kamal Ibrahim Mursi, aktivitas konseling Islam pada masa Islam klasik dikenal dengan hisbah atau ihtisab. Konselornya disebut muhtasib sedangkan kliennya disebut muhtasab 'alaih (Mubarok, 2000: 79). Hisbah menurut pengertian syara' artinya menyuruh orang untuk melakukan perbuatan baik yang jelas-jelas ia tinggalkan, dan mencegah perbuatan mungkar yang jelas-jelas dikerjakannya. Seorang muhtasib akan memanggil orang-orang yang bermasalah itu dan membantu mereka agar dapat mengerjakan hal-hal yang menumbuhkan kesehatan fisik, mental dan social, dan menjauhkan mereka dari perbuatan yang meruksak (Mubarok, 2000: 79).

Hisbah dilakukan dengan prinsip suka sama suka, bersifat sugesti dan introspeksi, sehingga muhtasib menyadari betul manfaat perbuatan ma'ruf dan bahaya perbuatan mungkar, dan dengan itu klien terdorong pada perbuatan baik dan allergi terhadap yang mungkar, kuat motivasi positipnya dan padam motivasi negatipnya. Hisbah juga dilakukan dengan lemah lembut.

Khalifah Umar bin Khattab adalah orang pertama yang mengatur pelaksanaan hisbah sebagai suatu sistem dengan merekrut dan mengorganisir muhtasib dan kemudian menugaskan mereka ke segala pelosok kaum muslimin guna membantu orang-orang bermasalah. Menurut Ibn Khaldun, hisbah itu merupakan tugas keagamaan dalam bidang amar m'ruf nahi mungkar, sebagai bagian dari kewajiban pemerintah.

Menurut Kamal Ibrahim Mursi (Mubarok, 2000: 84-85), hisbah waktu itu mengambil bentuk sebagai berikut:

1. Pemberian nasihat baik secara umum, secara perorangan dan kelompok, di masjid, di rumah dan di tempat kerja. 
2. Bimbingan individual, diberikan kepada individu yang nyatanyata membutuhkan, diminta ataupun tidak diminta. Objek bimbingannya dapat menyangkut masalah keagamaan, kerumahtanggaan, kepribadian, pekerjaan dan sebagainya.

3. Konseling individual, diberikan kepada individu yang terangterangan telah melakukan perbuatan tercela/keji, terangterangan tidak mau mengerjakan perbuatan baik, akrab dengan kejahatan dan allergi terhadap kebaikan. Orang pada tingkat ini biasanya sudah tidak mempan diberikan nasihat secara lemah lembut. Tahap hisbah seperti ini dilakukan dengan cara, muhtasib memposisikan dirinya sebagai seorang sahabat yang mempunyai kepedulian, secara sengaja mengetuk keras-keras pintu hati klien semacam schok terapiagar pintu hatinya bias terkuak, karena ketukan halus tidak akan pernah didengar atau bahkan ditertawakan.

4. Bimbingan massal, dilakukan untuk mendamaikan perselisihan antara kelompok-kelompok yang bertikai, dilakukan secara terbuka dalam forum perdamaian.

Konseling pada masa klasik Islam, jika ditela'ah menurut konseling modern, tampak lebih proaktif dalam mengatasi masalah. Konselor tidak bekerja sebatas ketika klien yang butuh bantuan datang kepadanya. Pada konseling Islam klasik, konselor merupakan pekerja pemerintah dan diberi wewenang untuk melakukan dakwah amar ma'ruf nahi mungkar, turut bertanggung jawab atas terciptanya kondisi yang harmonis, penuh dengan kebaikan dan menjauhi kemungkaran. Dengan gayanya yang proaktif hisbah sangat menekankan pendekatan preventif, mencegah daripada mengobati, mengantisipasi sedini mungkin merebaknya perilaku atau perbuatan yang berbahaya, perbuatan yang merugikan keselamatan baik individu yang bersangkutan maupun bagi masyarakat kebanyakan.

\section{Tumbuhnya Konseling Agama di Era Modern}

Kehidupan modern dengan kehebatan ilmu pengetahuan dan teknologi serta kemajuan ekonomi seperti yang dialami oleh bangsabangsa Barat ternyata telah menimbulkan berbagai suasana kehidupan yang tidak memberikan kebahagiaan batiniah dan berkembangnya rasa 
kehampaan. Mereka menyadari bahwa kemajuan itu telah memisahkan nilai-nilai spiritual sebagai sumber kebahagiaan hidup dan dirasakan oleh mereka sebagai satu kekurangan (Surya, 2008: 6)

Kehidupan yang terlalu berorientasi kepada kemajuan dalam bidang material (pemenuhan kebutuhan biologis) telah menelantarkan supra empiris manusia, sehingga terjadi pemiskinan rohaniah dalam dirinya. Kondisi ini ternyata sangat kondusif bagi berkembangnya masalah-masalah pribadi dan sosial yang terekspresikan dalam suasana psikologis yang kurang nyaman, seperti: perasaan cemas, stress, dan perasaan terasing, serta terjadinya penyimpangan moral atau system nilai (Yusuf, 2005: 487).

Dalam suatu penelitian terhadap masyarakat Barat dikemukakan bahwa akibat sampingan dari gaya hidup modern, seperti di negaranegara industri adalah munculnya berbagai problema sosial dan personal yang cukup kompleks. Problema tersebut seperti: (1) ketegangan fisik dan psikis, (2) kehidupan yang serba rumit, (3) kekhawatiran atau kecemasan akan masa depan, (4) makin tidak manusiawinya hubungan antar individu, (5) rasa terasing dari anggota keluarga dan anggota masyarakat lainnya, (6) renggangnya tali hubungan kekeluargaan, (7) terjadinya penyimpangan moral dan system nilai, (8) hilangnya identitas diri (Yusuf, 2005:487).

Mengacu kepada ciri dari sisi gelap kehidupan modern sebagai dampak modernitas, mengilhami para ilmuan yang masih yakin dengan agamanya, khususnya para ilmuan muslim. Menurut para ilmuan muslim, Barat terlampau menggeneralisir agama sebagai penghambat kemajuan dan pengekang kemajuan ilmu pengetahuan. Mereka tidak menyadari atau tidak mengetahui bahwa tidak semua agama menghambat kemajuan dan mengekang kemajuan ilmu pengetahuan. Agama tertentu seperti Islam justru sangat mendukung kemajuan peradaban. Agama Islam bukanlah sebuah kekuatan yang menahan kemajuan dan otonomi manusia. Islam malahan menyuruh umatnya untuk selalu menggali ilmu pengetahuan dan mengolah dunia untuk kehidupan yang baik bagi manusia.

Di era modern, manusia semakin menyadari bahwa dirinya telah kehilangan makna, tidak berdaya dalam kerangkeng yang kuat. Ia menjadi manusia yang kosong, resah setiapkali harus mengambil 
keputusan. Ia tidak tahu apa yang diinginkan, dan tidak mampu memilih jalan hidup yang diinginkan. Manusia modern begitu sibuk dan bekerja keras melakukan penyesuaian diri dengan tren modern. Ia merasa sedang berjuang keras untuk memenuhi keinginannya, padahal yang sebenarnya mereka diperbudak oleh keinginan orang lain, oleh keinginan sosial (Mubarok, 2005:184).

Krisis keruhanian sebenarnya berkaitan erat dengan pandangan hidup seseorang. Pandangan hidup yang salah akan mengakibatkan logika yang salah dalam merespon realita. Pandangan hidup menyangkut tujuan hidup, tugas hidup, fungsi hidup, lawan dan kawan hidup. Perbedaan pandangan hidup dapat mengakibatkan perbedaan pandangan tentang makna kenikmatan dan penderitaan, keberhasilan dan kegagalan, besar dan kecil, penting dan tidak penting, serta ketenangan dan kegelisahan (Mubarok,2005: 186).

Pemaparan di atas mengantarkan pada pentingnya tawaran konseling religius. Walaupun kemunculan tawaran ini dianggap kesiangan karena menurut sementara kalangan atau yang membuat fase-fase zaman lebih tepat ada setelah era modern (era post-modern) sebagai bentuk bangkitnya kesadaran akan berbagai kekurangan dan kelemahan yang dialami. Namun demikian bagi kondisi masyarakat tertentu seperti di Indonesia atau pada beberapa belahan di tanah air karakteristik modernitas boleh jadi baru tumbuh dan berkembang. Kesadaran era post-modern ini dapat saja diperkenalkan kepada mereka sehingga ketika menjalani kehidupan modern itu menjadi tidak kebablasan.

John Mc Leod (2008: 317-318) menyebutkan secara keseluruhan praktik konseling dan psikoterafi masuk dalam apa yang banyak disebut sosiolog sebagai modernitas, maksudnya filosofi, pemikiran dan bahkan pendekatan konseling menggunakan gaya dan logika modernitas. Praktek konseling dan psikoterafi di Barat pada masa itu belum menyadari kelemahan dan kekurangannyan yang ada pada modernitas. Para konselor waktu itu bangga dengan filsafat hidup modernitas yaitu yang ditandai dengan penggantian keyakinan religius dan nilai tradisional yang telah ada sebelumnya. Tren ini berubah seiring dengan melajunya zaman, di akhir abad ke-20 sebagian besar orang mulai berubah, globalisasi yang diasosiasikan dengan modernitas mengancam 
banyak nilai dan ritual tradisional, serta bentuk komunitas, yang sangat esensial bagi kebahagiaan. Teori-teori konseling pada era modernitas dipandang sebagai naratif agung yang disikapi skeptisme. Teori tersebut tidak lebih dari cerita yang dikisahkan dalam beberapa kantong kebudayaan, tidak membangun kebenaran ilmiah universal. Perhatian para terapis post-modern kemudian beralih pada klien dan terapis dan bagaimana cara menggunakan cerita ini untuk membangun hubungan dan memandu tindakan. Fokusnya lebih banyak diberikan kepada apa yang terjadi antara orang-orang ketimbang apa yang terjadi dalam diri mereka sendiri.

Djamaludin Ancok menyebut ada tiga aliran psikologi modern dan ia banyak melakukan kajian kritis terhadapnya sebagai psikologi modernitas yaitu psikoanalisis, behaviorisme dan humanistik. Menurut Ancok, teori Freud yang mengungkapkan bahwa satu-satunya hal yang mendorong kehidupan manusia adalah id (libido seksualita) adalah teori yang mendapat tantangan keras. Teori ini dianggap terlampau menyederhanakan kompleksitas dorongan hidup yang ada dalam diri manusia. Dorongan hidup manusia bukan hanya seks, dan tidak mampu menjelaskan dorongan lainnya termasuk dorongan yang dimiliki muslim untuk mendapatkan ridha dari Allah SWT (Ancok, 2005: 67). Kritik Ancok kepada aliran psikologi behavioris, aliran ini terlalu mengingkari potensi alami manusia, terlalu deterministik dan mereduksi manusia. Aliran ini tidak memiliki jiwa, tidak memiliki kemauan dan kebebasan untuk menentukan tingkah lakunya sendiri. Sedangkan kritiknya terhadap humanistik, walau humanistik dianggap memiliki banyak keunggulan dan lebih dekat dengan Islam tetapi celah kelemahannya bukan tidak ada. Pandangan humanistik terlalu optimistik terhadap upaya pengembangan sumber daya manusia, sehingga manusia dipandang sebagai penentu tunggal yang mampu melakukan play-God (peran tuhan) (Ancok, 2005: 67-69).

Kemunculan konseling religius Islam sebagai tawaran konseling di era modernitas khususnya untuk negara yang sedang berkembang seperti Indonesia, mencoba menghadirkan pikiran postmodern yang sudah melesat itu dan menerapkannya untuk kondisi hidup masyarakat modern. 


\section{E. Saat Konseling Islam Didiskusikan}

Pembahasan konseling bernuansa agama, tidak dapat menjauhkan diri dari diskusi panjang tentang konseling Islam. Di dunia ini tidak kurang dari 5 milyar penduduk dunia dan 1,3 milyar di antaranya memeluk agama Islam. Islam sebagai agama besar di dunia, telah memiliki sejarah besar dalam mengukir peradaban umat manusia, sumbangsih Islam terhadap peradaban dunia telah diakui, Islam menjadi sumber insfirasi kebaikan, motivator kemajuan, perekat persaudaraan, panduan dan tuntutan hidup bahagia dan sejahtera, petunjuk, rahmah dan sifa atas berbagai kemelut dan permasalahan hidup manusia.

Apakah itu konseling Islam? Apakah konseling Islam memiliki konsep-konsep yang jelas, seperti apakah dasar-dasar konseling yang bernafaskan Islam itu, seperti apakah metode konseling yang bernafaskan Islam itu. Pertanyaan-pertanyaan semacam ini dijawab melalui berbagai seminar. Seminar nasinonal Bimbingan dan Konseling Islam I pada tanggal 15-16 Mei 1985, dari seminar diperoleh rumusan bahwa konseling Islami adalah suatu proses dalam bimbingan dan konseling yang dilakukan dengan mendasarkan pada ajaran Islam, untuk membantu individu yang mempunyai masalah guna mencapai kebahagiaan dunia dan akhirat. Subyek yang dibimbing adalah individu bermasalah yang membutuhkan bantuan bimbingan dan konseling. Pembimbingnya adalah individu yang memiliki kewenangan (kompetensi) untuk melakukan BK Islami yaitu: (a) ahli bimbingan

konseling Islami (konselor), (b) ahli psikologi, (c) ahli pendidikan (pedagok), (d) ahli agama Islam (ulama), dokter, dan (f) pekerja social. Isi BK Islami mencakup hal-hal yang berkaitan dengan kebutuhan individu yang sedang menghadapi masalah berupa kebutuhan jasmani dan ruhani untuk mencapai kebahagiaan dunia dan ukhrowi. Jenis-jenis BK Islami mencakup: bimbingan konseling perkawinan dan keluarga, bimbingan dan konseling jabatan atau pekerjaan, bimbingan dan konseling social, dan bimbingan konseling klinis.

Prinsip-prinsip dasar bimbingan dan konseling Islami (a)berkaitan dengan tujuan, BK Islami ditujukan kepada individu dalam rangka mencapai kebahagiaan dunia dan akhirat sejalan dengan ajaran Islam, (b)berkenaan dengan pembimbing dan individu yang dibimbing, 
BK Islami dilakukan oleh dan untuk manusia sesuai dengan pandangan Islam mengenai hakikat manusia, (c) berkenaan dengan isi (materi), BKI berlandaskan pada ajaran Islam, isi (materi) BKI adalah ajaran Islam, (d) berkenaan dengan proses, BKI berlandaskan pada ukhuwah Islamiyah (hubungan insane yang berlandaskan pada ajaran Islam).

Pandangan Islam tentang hakikat manusia harus menjadi landasan utama BKI. Manusia dipandang sebagai mahluk ciptaan Allah yang memiliki karakteristik: (a) terdiri dari unsur jasmani dan rohani, (b) manusia memiliki kemampuan rohani berupa cipta (akal), rasa (afektif), karsa (nafsu/kehendak), (c) ada unsure-unsur dinamis pada manusia: manusia sebagai mahluk individu, mahluk social, mahluk budaya, dan mahluk religious, (d)ada keutuhan dan keseimbangan pengembangan unsure-unsur (jasmani-rohani, cipta-rasa-karsa, duniawi-ukhrawi)pada manusia, (e) hakikat keberadaan (eksistensi) manusia; manusia dibekali dengan potensi dan kecenderungan tertentu, manusia adalah mahluk yang unggul, manusia bias berkembang kea rah kebaikan dank e arah ketidak-baikan, manusia memiliki potensi yang berbeda antara manusia satu dengan lainnya, meskipun ia telah dilengkapi dengan berbagai potensi tetapi kemampuannya terbatas, ada kebebasan pada manusia untuk memilih tetapi ada tanggung jawabnya di hadapan Allah, (f) manusia adalah mahluk yang aktif dan kreatif, dan (g) manusia adalah mahluk yang bertanggung jawab.

Seminar dan Loka Karya Bimbingan dan Konseling Islami II yang diselenggarakan di Universitas Islam Indonesia (UII) Yogyakarta tanggal 15-17 Oktober 1987 diperoleh beberapa catatan penting, bahwa layanan BK Islami bukan hanya mengupayakan mental yang sehat dan kehidupan yang sejahtera, lebih dari itu juga menemukan jalan hidup menuju kehidupan yang sakinah, batin merasa senang dan tentram lantaran selalu dekat dengan Allah SWT.

Seminar dan Loka karya BKI II berhasil merumuskan beberapa konsep dasar BKI dalam bidang (a) pernikahan, (b)pendidikan, (c)pekerjaan/karir, (d) social kemasyarakatan, dan (e)bidang keagamaan. Di samping itu juga disusun wadah organisasi pembimbing Islami yang diberi nama Perhimpunan Pembimbing Islam Indonesia (PPII), dengan status di bawah Ikatan Petugas Bimbingan Indonesia (IPBI) sekarang ABKIN. Anggota PPII terdiri dari petugas BP di sekolah, 
guru agama, mubaligh/ulama, psikolog, sosiolog, dokter dan paramedic, psikister, cendikiawan muslim, pekerja social, dan pendidik atau ahli pendidikan. Anggota harus beragama Islam, sifat keanggotaan aktif artinya berminat menjadi anggota dan mendaftarkan diri.

Dirumuskan pula kode etik BKI yaitu (a) pembimbing harus menghargai harkat martabat manusia sebagai mahluk ciptaan Allah yang paling sempurna, (b) pembimbing harus memiliki keahlian dalam bidang bimbingan, (c) pembimbing harus senantiasa menjaga amanah dan rahasia individu yang dibimbing, (d)pembimbing harus menjaga nilai-nilai ukhuwah islamiyah, (e)pembimbing harus memiliki sifat-sifat yang patut diteladani (uswah hasanah), (f)pelaksanaan bimbingan harus sesuai dengan syari'at Islam, (g) pembimbing member kebebasan kepada individu yang dibimbing untuk mengikuti atau tidak mengikuti nasihat pembimbing, (h)layanan bimbingan didasari dengan niat mencari ridha Allah, (i) sebisa mungkin konseli laki-laki dibimbing oleh pembimbing laki-laki, dan konseli perempuan dibimbing oleh pembimbing perempuan, (j) penanganan kasus hendaknya didasarkan atas prinsip amar ma'ruf nahyi mungkar.

\section{F. Konseling Islam sebagai Fenomena Keilmuan}

Salah satu permasalahan konseling Islam sebagai ilmu, berkait dengan posisinya, apakah konseling Islam sebagai ilmu merupakan disiplin ilmu yang berdiri sendiri atau merupakan pecahan dari ilmu lain yaitu konseling, karena pertimbangan pendekatan yang dikedepankan berbasis agama/Islam sehingga konseling Islam menjadi disiplin ilmu yang mandiri dengan identitas kelamin yang jelas yaitu pendekatan Islam.

Seandainya konseling Islam merupakan disiplin yang tidak terkait dengan ilmu sebelumnya, apakah ini mungkin? Di dunia ini tidak ada perkembangan ilmu atau kelahiran sebuah ilmu yang tidak didahului oleh pikiran-pikiran sebelumnya, apalagi konseling Islam yang berkembang masih baru, dalam kenyataannya sebelum konseling Islam ini digagas dan dilahirkan sebelumnya sudah ada konseling, yaitu konseling berbasis pendidikan, yang di Indonesia sudah berlangsung sejak tahun 1975 (Juntika, 2006:6), atau di dunia dengan sejarah awal 
perkembangannya terjadi sekitar awal abad XX dan perkembangannya menjadi pesat pada tahun 1950-an di Amerika Serikat (Juntika,2006:4).

Sementara itu dalam tradisi masyarakat Islam, kegiatan layanan bantuan yang bersifat psikhis ini dan bahkan bersifat spiritual berupa layanan bantuan yang bersifat spiritual, sudah ada semenjak masyarakat Islam ini ada. Dalam masyarakat Islam kegiatan memberikan layanan bantuan yang bersifat spiritual dan psikologis ini memiliki padanan yang tepat dengan aktivitas dakwah atau bagian dari dakwah, sebab dakwah hakikatnya merupakan upaya yang dilakukan oleh seorang da'i yang telah lebih dahulu mendapatkan keberkahan hidup secara Islam, yaitu melalui pengetahuan dan keyakinan islam yang dimilikinya, pertama, dia mampu melangsungkan kehidupannya, melakukan pengaturan, pengarahan dan pengawalan diri untuk tetap berada di jalan tuhannya. Dengan pengetahuan dan keyakinan islam seorang muslim mampu berdiri kokoh, tahan banting terhadap berbagai kesulitan hidup, tangguh dan unggul, berdaya saing dan mampu menjalani kehidupan dengan penuh kesuksesan. Setelah yang pertama, kemudian seorang muslim mau berbagi dengan yang lain, dan bahkan dengan dasar perwatakan yang dibangun oleh keyakinan agama Islam ini, seorang muslim terdorong untuk banyak melakukan amal shaleh, dan dengan dasar cinta dan kasih sayang mau menolong sesamanya, menunjukkan, memberikan arahan, memberikan nasihat, dan pertolongan kepada muslim lainnya yang masih berada dalam keterbelakangan, kegelapan, kesusahan, kesulitan agar mampu bangkit dan berbuat secara mandiri untuk meraih kehidupan yang lebih baik. Kondisi ini sejalan dengan hakikat inti dari kegiatan dakwah 'yukhrijuhum minad-dhulumaati ila al-nur'. Jadi layanan konseling hakikatnya merupakan layanan bantuan yang diberikan secara tulus dan ikhlas, penuh dengan kasih sayang dan cinta kasih sebagai bagian dari manifestasi pemahaman dan penghayatan seorang muslim terhadap nilai ajaran Islam.

Refleksi penulis ini sejalan dengan pikiran Isep Zainal Arifin, yang mencoba memposisikan disiplin keilmuan konseling Islam. Menurut Isep (2009: 12), posisi konseling islam berada pada sub struktur dari disiplin ilmu dakwah yaitu irsyadul Islam. Namun demikian dalam pemikiran Isep, karena konseling Islam berbasis ilmu dakwah, konseling Islam (irsyad) didefinisikan sebagai internalisasi dan transmisi ajaran 
Islam. Sekilas saja sudah terlihat betapa rumusan tersebut sangat bernuansa dakwah, sedangkan pemaknaan konseling yang dikehendaki dalam terminologi kontemporer lebih kepada layanan perbantuan atau asistensi. Jika menurut Isep, fokus utama kegiatan internalisi dan transmisi ajaran Islam mencakup bin-nafsi, zikrullah, do'a, wiqayat alnafs, tazkiyyat al-nafs, shalat, puasa, ta'lim, taujih, mauizhah, nasihah dan isytisyfa (Arifin, 2009: 3), maka dalam konseling kontemporer, keberadaan istilah-istilah yang disebutkan itu dapat menjadi metode dalam pelaksanaan konseling.

Isep menyebut konseling dakwah dengan counseling for all. Kemunculan istilah ini karena cara berpikirnya untuk menanggapi dua posisi konseling sebelumnya yang masing-masing, antara lain berada pada dua keilmuan dan bidang keahlian yang sudah mapan selama ini yaitu pendidikan dan psikologi (Isep, 2009: 12). Sementara itu daya dorong lain yang muncul berupa kegerahan intelektual kedakwahan melihat fenomena ini yang memandang ada sub ilmu dan keahlian yang lebih relevan dengan aktivitas layanan konseling ini yaitu dakwah Islam. Isep membagi konseling menjadi konseling pendidikan, konseling psikologis dan konseling dakwah.

Penulis memiliki pandangan sendiri, konseling Islam tidak mesti harus memadukan keduanya, karena ingin mencakup keduanya kemudian memberikan penamaan khusus dengan counseling for all. Konseling Islam ya konseling Islam, tidak menjadi konseling pendidikan atau konseling psikologis. Sejarah kemunculannya bisa saja dipicu oleh karena bangkitnya kesadaran keilmuan dari kalangan sekuler yang tidak bisa menutup mata atas realitas kegersangan spiritual, yang kemudian diduga menjadi akar segala permasalahan umat manusia di zaman modern, juga bisa saja tanpa terkait atau dikaitkan dengan fenomena berkembangan konseling spiritual/bernuansa keagamaan pada lapang keilmuan lain. Misalnya seorang muslim dapat saja memandang konseling Islam sebagai bentuk aktivitas shaleh seorang muslim dalam sepanjang sejarah kehidupan yang dipicu karena manifestasi keimanan dan keislamannya. Inti aktivitas shaleh ini yaitu aktivitas menolong sesama muslim yang mengalami permasalahan dalam hidupnya, belum mendapatkan hidayah, belum tercerahkan, belum tersadarkan, dan masih merasa kebingungan dalam menjalani kehidupannya. Aktivitas ini memiliki dasar yang kuat dalam ajaran Islam (tawaa shaubil-haqq, 
tawaa shaubis-shabr; wallahu fii 'auni 'abdi maa kaanal 'abdu fii 'auni akhiihi; ud'u ilaa sabiili rabbika bil-hikmati, wal mau'idzatil hasanati wa jaadilhum billatii hiya ahsan..; ta'aawanuu 'alal birri wat taqwa walaa ta'aawanuu 'alal itsmi wal 'udwan).

Penjelasan objektif aktivitas perbantuan ini boleh jadi memiliki relevansi yang kuat dengan aktivitas dakwah Islam, sebab semua aktivitas untuk menunjukkan orang lain agar hidup secara Islam dapat dikelompokkan pada lingkup kegiatan dakwah Islam, jangankan konseling Islam, pendidikan Islam saja dapat disebut dakwah Islam, bahkan kegiatan jual beli asal saja dalam prosesnya mendemonstrasikan cara jual beli muslim yang taat terhadap ajaran agamanya, yang dengan itu membuat orang lain kenal dan tertarik dengan cara jual beli itu, maka aktivitas itu menjadi dakwah Islam.

Permasalahan apakah konseling Islam itu merupakan konseling pendidikan, atau konseling psikologis atau konseling dakwah tergantung pada cara pandang seseorang dalam melihat fenomena aktivitas konseling Islam atau dikenal dengan paradigma. Jadi permasalahan ini sangat bergantung pada paradigma mana konseling Islam itu dilihat. Adanya fleksibilitas ini, jika tidak mau dikatakan adanya politik kepentingan dan keberpihakan, memungkinkan berkembangnya disiplin dan skill konseling Islam pada ketiga ilmu itu, atau jelasnya dimungkinkan terbukanya pendirian prodi konseling Islam pada tiga fakultas masing-masing fakultas pendidikan Islam, fakultas psikologi Islam dan fakultas dakwah. Perbedaan atau irisan ketiganya sangat tipis, tinggal kompromi atau saling pengertian sesuai dengan kebutuhan. Dan dapat juga berdiri sendiri tanpa menyandarkan diri pada disiplin ilmu manapun, karena dalam kenyataannya masih sulit menemukan padanan yang tepat ketika menggunakan istilah arab terhadap konseling Islam yang dimaksud.

Menurut Lubis (2007: 79), dalam literature Arab kata konseling memiliki padanan yang tepat dengan al-irsyad atau al-Istisyarah. Dengan demikian konseling Islam adalam term Arab disebut irsyadul Islam. Lubis menyimpulkan beberapa batasan konseling Islam (Lubis, 2007: 97-98) antara lain:

a. Konseling Islam adalah layanan bantuan kepada konseli agar konseli mampu mengetahui, mengenal dan memahami keadaan 
dirinya sesuai dengan hakikatnya, atau memahami kembali keadaan dirinya.

b. Konseling Islam adalah layanan bantuan kepada konseli untuk menerima keadaan dirinya sebagaimana apa adanya, segi-segi baik dan buruknya, kekuatan dan kelemahannya, sebagai sesuatu yang ditretapkan Allah. Kemudian menyadarkannya bahwa sebagai manusia ia diwajibkan berikhtiar. Kelemahan pada dirinya bukan untuk terus menerus disesali, dan kekuatan yang ada pada dirinya bukan untuk membuatnya lupa diri. Dengan kata lain konseling Islami bertujuan untuk mendorong dan mengarahkan konseli untuk tawakkal/berserah diri kepada Allah, mengkonsultasikan segala permasalahan kepada Allah dan sekaligus memohon petunjuk dan pertolongan-Nya untuk menyelkesaikan setiap permasalahan yang dihadapinya.

c. Konseling Islam adalah layanan bantuan kepada konseli untuk memahami keadaan (situasi dan kondisi) yang dihadapinya saat ini. Dalam hal ini, ia dibantu untuk merumuskan masalah yang dihadapinya dan sekaligus mendiagnosis masalah tersebut. Selanjutnya membantu konseli untuk menemukan sendiri alternative pemecahan masalah. Konselor hanya dalam batas menunjukkan alternatif yang disesuaikan dengan kadar intelektual konseli bersangkutan.

Permasalahan lain tentang konseling Islam sebagai fenomena keilmuan, berkait dengan objek studi keilmuan baik objek material maupun objek formal. Dalam kajian filsafat ilmu, sebuah pengetahuan dikatakan sebagai ilmu jika pengetahuan itu memiliki objek studi yang jelas, terutama objek formal, karena kejelasan objek ini menjadi identitas dan ciri pembeda antara satu ilmu dengan ilmu lain (Bisri, 1994: 6). Demikian juga dengan konseling Islam, selama ini sejumlah literatur belum banyak atau kalau tidak mau dikatakan tidak ada, pemikir atau ahli yang membicarakan objek studi konseling Islam. Berpijak pada fakta berlangsungnya aktivitas konseling oleh Rasulullah dan didukung oleh sejumlah keterangan baik dalam al-Qur'an maupun al-Hadits. Misalnya hadits Nabi berbunyi: "man nafasa kurbatan min kurabid-dunya naffasahullahu kurbatan min kurabil akhirah (al-Hadits)". Tindakan menolong dan meringankan beban orang lain termasuk 
amaliyah shalihah yang sangat dihargai Allah, disebut juga amaliyah ihsan, dalam al-Qur'an surat al-Imran: 153, perbuatan ihsan sangat dicintai oleh Allah swt. Berdasarkan sumber ajaran dan praktek empiris Rasul dan para sahabat, maka objek material konseling Islam adalah perilaku ihsani, mungkin juga perilaku Islami dan imani. .

Perilaku iman, islam dan ihsan itu cakupannya luas, dan karena luasnya perilaku ini sangat boleh jadi perilaku ini telah menjadi objek ilmu lain seperti ilmu dakwah, ilmu ekonomi Islam, ilmu politik Islam, ilmu jiwa Islam, ilmu tasawuf, dan lain-lain. Untuk itu pembahasan tentang objek ini harus diperjelas dengan penyebutan objek lain yaitu objek formal, dengan objek formal wilayah kajian konseling Islam menjadi jelas, yaitu perilaku perbantuan (asistensi) yang dilakukan oleh seorang muslim yang taat kepada Allah dan Rasulnya serta berkepribadian imani, islami dan ihsani kepada individu-individu yang membutuhkannya. Perilaku bantuan ini juga masih cukup luas maknanya, boleh jadi perilaku bantuan itu dalam bentuk permodalan, pemberian pinjaman atau pemberian cuma-cuma, pemberian bantuan dalam bentuk pengarahan, nasihat, pemberian informasi, pencerahan ilmu, layanan pengaduan, curhat, layanan diskusi, layanan gagasan dan pendapat, layanan pelatihan, layanan pengembangan, bantuan penyembuhan dan pengobatan, layanan perawatan ruhani Islam, layanan pengembangan pribadi sehat, pengembangan pribadi bermutu dan berkemampuan, dan lain-lain.

Objek formal konseling Islam membatasi diri pada aktivitas memberikan bantuan secara spiritual-Islami dan psikologis-Islami terhadap sejumlah permasalahan individu yang berkaitan dengan karakter buruk yang sulit dihindari, kepribadian yang menyimpang dari norma-norma agama, susila dan budaya, kebiasaan-kebiasaan negatif serta masalah-masalah kejiwaan seperti problem kecemasan, ketakutan, kesedihan.

Pemberian bantuan secara spiritual Islami maksudnya kegiatan perbantuan dengan cara mengajarkan kepada individu bermasalah tentang keterampilan spiritual-Islam tertentu yang dibutuhkan berkenaan dengan penanganan masalah yang dihadapinya. Spiritual Islami biasanya dipahami sebagai napas Islam, hal ini dapat dipahami dari istilah spiritual sendiri yang berasal dari kata Latin spiritus yang 
berarti napas (Sutardjo, 2009). Spiritus juga menyerupai spirtus yang biasa digunakan oleh seseorang yang akan menyalakan lampu petromak, sifatnya membakar dan memperbesar daya api, asosiasi terhadap gambaran ini bahwa spiritus mampu memompakan semangat yang besar. Jika spiritus dikaitkan dengan Islam maka sesuatu yang mampu memompakan semangat itu bersumber dari nilai-nilai ajaran Islam.

Bantuan spiritual-Islami memiliki fokus orientasi penguatan nilainilai moral dan nilai ibadah Islam. Nilai moral Islam seperti kejujuran, amanah, kesetiaan, keadilan, komitmen, kasih sayang, kebersamaan, keshabaran, keharmonisan. Bantuan spiritual-Islami juga memiliki fokus orientasi penguatan nilai ibadah Islam seperti kekhusu'an dalam ibadah, keikhlasan, keistiqamahan. Bagaimanakah bantuan spiritual-Islami ini mampu memberikan penguatan nilai moral dan ibadah pada diri seseorang, tentu harus diupayakan dengan teknik dan metode tertentu misalnya dengan memberikan penjelasan rasional berkait dengan keutamaan dan manfaat berpegang teguh dan mengamalkan nilai-nilai moral dan kualitas peribadahan dalam Islam.

Sedangkan pemberian bantuan secara psikologis-Islami maksudnya kegiatan pemberian bantuan dengan sasaran penguatan daya psikologis-Islami seperti keshabaran, ketawakallan, kepasrahan, kesungguh-sungguhan. Menurut Mubarok (2000: 5) upaya melakukan penguatan daya psikologis-Islami tiada lain adalah dengan meningkatkan keimanan dan ketakwaan. Iman dan takwa memiliki korelasi yang erat dengan penguatan daya psikologis-Islami seperti keshabaran, kepasrahan dan kepasrahan dan kesungguh-sungguhan. Semakin kuat keimanan seseorang kepada tuhannya maka semakin bagus keshabaran yang dimilikinya. Seseorang akan mampu menahan segala keinginannya, mengurangi desakan-desakan biologisnya karena demi meraih ridha dan cinta Allah Swt. Semakin seseorang menyadari dan mengimani kebenaran ajaran-ajaran agama tentang keshabaran, kepasrahan, kesungguh-sungguhan lengkap dengan pemahaman hikmah-hikmah di balik perintah, semakin kuat orang menjalani praktek keshabaran, kepasrahan dan kesungguh-sungguhan. Dalam konteks kehidupan manusia di dunia, keberadaan daya psikologis-Islami itu sangat dibutuhkan, boleh jadi dapat menentukan pencapaian harapan dan kesuksesan di masa yang akan datang, menentukan keselamatan 
dan kebahagiaan, tidak terjerumus pada narkoba, pada korupsi (unexpected behavior), sebaliknya energy negative diubah menjadi energy positif yang melahirkan perilaku-perilaku yang diharapkan (expected behavior).

\section{G. Penutup}

Posisi dan peta keilmuan konseling Islam berada dalam kutub tarik menarik antara pendidikan, psikologi dan dakwah. Ketiganya memiliki celah untuk mengembangkan konseling Islam. Pendidikan memandang konseling sebagai perangkat teknik dalam pendidikan, tugas seorang guru, sebuah layanan bagi pengembangan potensi anak didik baik pada jalur pendidikan formal maupun non-formal dan informal. Seperti halnya pendidikan, psikologi juga memandang konseling sebagai bentuk aplikasi dari psikologi. Setelah psikologi melakukan pendalaman tentang jiwa selanjutnya terhadap temuantemuan psikologi itu mereka lanjutkan dengan konseling. Konseling menjadi bentuk praktek atau pengabdian ilmu bagi psikolog. Sementara itu dakwah juga memandang lebih berhak terhadap skill konseling, sebab dalam dakwah, aktivitas konseling itu sudah lama dilakukan oleh umat Islam dan menyatu dengan kegiatan dakwah. Kemudian, dimanakah sebaiknya konseling Islam secara institusional sebaiknya dilembagakan? Barangkali dengan mengedepankan kearifan, dan didasarkan pada kebutuhan yang ril, sesuai dengan misi utama konseling sebagai layanan perbantuan dalam kerangka memperbaiki dan mensolusi permasalahan umat yang sangat sejalan dengan spirit dan kerangka pengembangan Ilmu dakwah maka pembukaan lembaga konseling Islam akan lebih baik dibuka di Fakultas Dakwah.[] 


\section{DAFTAR PUSTAKA}

Mubarok, Achmad. 2000. al-Irsyad an-Nafsy, Konseling Agama Teori dan Kasus. Jakarta: PT. Bina Rena Pariwara.

Lubis, Saiful Akhyar. 2007. Konseling Islami Kyai dan Pesantren. Yogyakarta: eLSAQ Press.

Sutoyo, Anwar. 2009. Bimbingan dan Konseling Islami Teori dan Praktik. Semarang: CV. Widya Karya.

Bisri, Cik Hasan. 1994. Pengembangan Wilayah dan Metode Penelitian Dakwah. Bandung: KP. Hadid.

Nurihsan, Achmad Juntika. 2006. Bimbingan dan Konseling dalam Berbagai Latar Kehidupan. Bandung: PT. Refika Aditama.

Ancok, Djamaludin. 2005. Psikologi Islami, Solusi Islam atas Problemproblem Psikologi. Yogyakarta: Pustaka Pelajar.

Surya, Moh. t.t. Mewujudkan Bimbingan dan Konseling Profesional. Bandung: Rosdakarya.

Arifin, Isep Zainal. 2009. Bimbingan Penyuluhan Islam. Jakarta: CV. Rajawali Press. 